\title{
CALCIUM METABOLISM OF BONE IN VITRO. INFLUENCE OF BONE CELLULAR METABOLISM AND PARATHYROID HORMONE*
}

\author{
By STEIN SCHARTUM ANd GEORGE NICHOLS, JR. $\dagger$ \\ (From the Departments of Medicine and Biochemistry, Harvard Medical School, Boston, Mass.)
}

(Submitted for publication May 8, 1961 ; accepted June 16, 1961)

As has been pointed out by McLean and Urist (1) and by Neuman and Neuman (2), the total $\mathrm{Ca}$ concentration in the circulating fluids can be considered to consist of two parts-that which is the result of the passive solubility of bone mineral, and that which is the result of bone cellular metabolic phenomena. These metabolic phenomena are thought to raise the Ca concentration above the level predicted by bone salt solubility and to be influenced by parathyroid hormone.

By analogy, in an in vitro system the final concentration of $\mathrm{Ca}$ (and $\mathrm{P}$ ) in the medium surrounding living bone samples should be partly the result of passive solubility equilibrium between bone mineral and the medium and partly the result of cellular metabolic activity. It has been shown in previous communications from this and other laboratories (3-5) that living samples of bone survive in vitro for appreciable periods and carry on active metabolism which can be modified by various changes in conditions. Measurement of Ca and $\mathrm{P}$ concentrations under steady state conditions in the incubation medium of such an in vitro system appeared to offer an opportunity to explore the influence of various aspects of cell metabolism upon the mobilization of these ions from bone. In addition, by incubating bone samples in which cellular activity had been destroyed, the fraction of the total concentration that could be assigned to passive solubility phenomena could be estimated.

The studies reported below were undertaken: first, to determine which fraction of the steady state $\mathrm{Ca}$ and $\mathrm{P}$ concentrations in the media could be attributed to passive solubility of bone mineral and which fraction appeared to depend upon the

\footnotetext{
* A preliminary report of this work was presented at the meeting of the American Physiological Society, Atlantic City, N. J., April, 1961. This work was supported by Grants A-854 (C4) and (C5) from the Institute of Arthritis and Metabolic Diseases.

$\dagger$ Markle Scholar in Medical Science.
}

metabolic activity of cells; second, to examine more directly which steps in the metabolic sequence and which metabolites of cells might be associated with mobilization of mineral from bone; and finally, to explore the effects prior treatment of the animals with parathyroid hormone might have on these phenomena.

The results of these experiments indicate that 18 per cent of the Ca concentration maintained by normal living bones in their surrounding media was related to metabolic phenomena; about onehalf of this being associated with glucose metabolism. No direct correlation, however, could be found between rates of lactate production (previously shown to be the chief end-product of glucose metabolism in this tissue) and Ca concentration. Parathyroid hormone treatment increased the total concentration of calcium 17 per cent above normal controls. The mechanism of this action appeared to involve both an increase in the passive solubility of the bone mineral and changes in the pattern of cellular metabolic effects. No effects on total $\mathrm{P}$ concentrations were observed in any of the experiments with surviving bone samples.

\section{METHODS}

A. Preparation of tissue samples. Adult white Swiss mice, 7 to 9 weeks old, were killed by cervical vertebra fracture, and the calvaria removed. The bones were freed from tendinous and muscular attachments by dissection, and adherent blood and clots were removed by washing the samples in ice-cold Krebs-Ringer bicarbonate medium. All bones were kept in fresh media stored on ice until the start of the incubation. After gentle blotting, two calvaria were pooled (about $100 \mathrm{mg}$ total weight), weighed, and placed in the incubating flask.

B. Heat-inactivation. When bone samples were killed by heating, the procedure was as follows. Samples of glucose-free medium were heated to boiling, removed from the gas flame, and the bone samples quickly added and kept in the hot media for 1.5 minutes. They were then transferred to freshly prepared media for incubation. 
C. Incubation. Unless otherwise indicated the samples were incubated in a Dubnoff metabolic incubator at $37.8^{\circ}$ $\mathrm{C}$ in $2 \mathrm{ml}$ of modified Krebs-Ringer media, ${ }^{1}$ buffered to $\mathrm{pH} 7.4$ with $\mathrm{HCO}_{3}{ }^{-}$and 5 per cent $\mathrm{CO}_{2}$. Penicillin at a final concentration of $5 \mathrm{U}$ per $\mathrm{ml}$ and streptomycin, 0.01 $\mathrm{mg}$ per $\mathrm{ml}$, were added to prevent bacterial growth. Glucose was used as substrate at a concentration of $2 \mathrm{mg}$ per $\mathrm{ml}$. During the incubation a continuous stream of 95 per cent $\mathrm{O}_{2}$ with 5 per cent $\mathrm{CO}_{2}$ was fed into the hood covering the flasks, which were left in the incubator without stoppers. All media were also equilibrated for 10 minutes with the appropriate gas before being placed in the flasks. Iodoacetate, when used, was at a final concentration of $0.9 \times 10^{-3} \mathrm{M}$ (6). Normal controls were incubated and compared with the experimental samples for each experiment.

D. Injection of parathyroid extract ${ }^{2}$ (PTE). Hormone-treated mice were injected subcutaneously with $0.15 \mathrm{ml}$ of PTE once daily for 3 successive days, the last injection being given 18 hours prior to sacrifice. The control group was injected with $0.15 \mathrm{ml}$ of distilled water at the same time.

E. Analytical techniques. Aliquots of the media were analyzed for $\mathrm{Ca}$ by the EDTA-calcium chelating method with murexide as an indicator, ${ }^{3}$ for $\mathrm{P}$ by the method of Fiske and Subbarow (7), and for lactate by a modification of Barker and Summerson's technique (8); $\mathrm{pH}$ in the media was determined by glass electrode with a Beckman $\mathrm{pH}$ meter, model $\mathrm{G}$. In the experiments in which $\mathrm{pH}$ was measured, the flasks were gassed separately through rubber stoppers. The $\mathrm{pH}$ was measured exactly 1.5 minutes after the stopper had been removed from the flask in order to equalize losses of $\mathrm{CO}_{2}$ from the media that would affect $\mathrm{pH}$.

$F$. Calculation. There was a tendency for minor shifts to occur in the absolute values from one day to another, while the relative differences between controls and experimental samples remained quite constant. For example, on one day the mean $\mathrm{Ca}$ value (4 incubations) was 0.64 mmole per $L$ for viable samples and 0.52 (3 incubations) for heat-inactivated samples. On another day the mean values ( 3 incubations in each case) obtained were 0.58 and 0.47 . The differences were 0.12 and 0.11 in these two experiments and in each case were significantly different, with a $\mathrm{p}$ value below 0.001 . Comparable differences in phosphate concentrations from day to day were observed. Therefore, all values have been calculated as per cent of normal controls for each experiment. In all experiments values obtained with living bone samples incubated in standard media with glucose under aerobic conditions have been used as normal controls. Bessel's correction for small samples was used in calculating standard deviations. The significance of the differences between means was estimated by means of Students' $t$-test.

1 The media contained no $\mathrm{Ca} ; \mathrm{P}$ was present at a concentration of 0.40 mmole per $\mathrm{L}$.

${ }^{2}$ Kindly supplied by Dr. Otto K. Behrens, Eli Lilly Co.

3 O. A. Iseri and P. L. Munson, personal communication.
G. Criterion of bone cell viability. In experiments where impairment of the cells might have been expected as a result of the incubating conditions, it was important that the viability of the bone samples be determined. Since lactate production is a prominent feature of the metabolism of bone cells in vitro (3), the rate of lactate production compared with controls in a subsequent incubation under normal conditions was used to judge viability in living samples. On the other hand, when bone samples were inactivated by heat, it was equally important to be sure that the heating procedure resulted in complete and permanent cessation of cellular metabolism. Inability of these samples to produce lactate was taken as evidence that their cells were dead.

\section{RESULTS}

\section{A. Time required to reach steady state and de- termination of passive solubility component of $C a$ and $P$ concentrations}

A significant period of incubation was required before the steady state concentrations of $\mathrm{Ca}$ and $P$, which the sample would maintain in the medium, were reached. Since a steady state concentration was to be used as the end-point in these studies, the determination of an appropriate time of incubation was important. It was equally important that the concentrations to be expected on a passive solubility basis be defined, if the role of cellular metabolism was to be examined. Therefore, $\mathrm{Ca}$ and $\mathrm{P}$ concentrations in media were

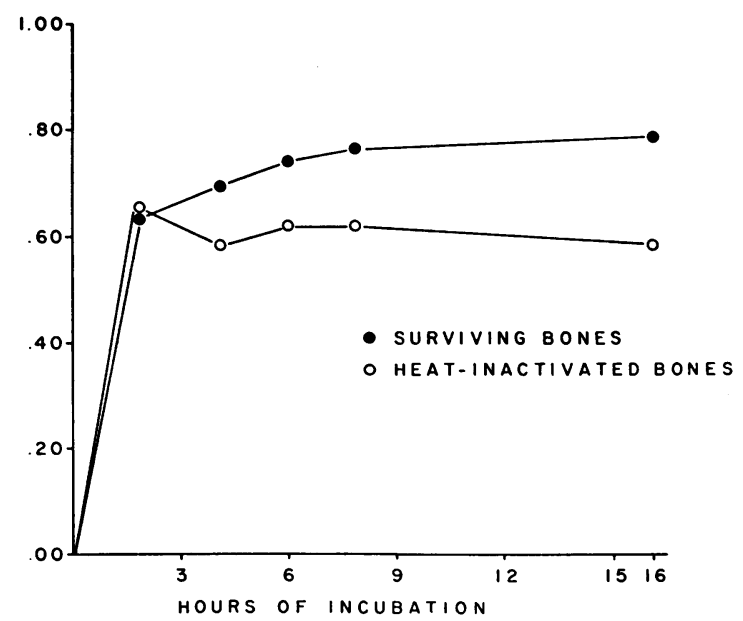

Fig. 1. Mean Ca concentrations in the media surROUNDING SURVIVING AND HEAT-INACTIVATED BONES. Data at 6 hours are the same as shown in Table I. Each point represents the mean of at least 8 incubations. Values on the ordinate are mmoles per $\mathrm{L}$. 
TABLE I

Effects of heat inactivation on bones from normal and PTE-treated animals

\begin{tabular}{|c|c|c|c|c|c|c|c|c|c|c|}
\hline \multirow[b]{2}{*}{$\begin{array}{l}\text { Exp. } \\
\text { day }\end{array}$} & \multirow[b]{2}{*}{$\begin{array}{l}\text { Incub., } \\
\text { hours }\end{array}$} & \multicolumn{3}{|c|}{$\mathrm{Ca}$} & \multicolumn{3}{|c|}{$\mathbf{P}$} & \multicolumn{3}{|c|}{$\mathrm{Ca} \times \mathrm{P}$} \\
\hline & & $\begin{array}{c}\text { Controls, } \\
\text { normal }\end{array}$ & $\begin{array}{c}\text { Heated, } \\
\text { normal }\end{array}$ & $\begin{array}{l}\text { Heated, } \\
\text { PTE-R }\end{array}$ & $\begin{array}{c}\text { Controls, } \\
\text { normal }\end{array}$ & $\underset{\text { normal }}{\text { Heated, }}$ & $\begin{array}{l}\text { Heated, } \\
\text { PTE-R }\end{array}$ & $\begin{array}{c}\text { Controls, } \\
\text { normal }\end{array}$ & $\begin{array}{c}\text { Heated, } \\
\text { normal }\end{array}$ & $\begin{array}{l}\text { Heated, } \\
\text { PTE-P }\end{array}$ \\
\hline $\begin{array}{l}1 \\
2 \\
3\end{array}$ & $\begin{array}{l}6 \\
6 \\
6\end{array}$ & $\begin{array}{l}0.64(4)^{*} \\
0.58(3) \\
0.59(3)\end{array}$ & $\begin{array}{l}0.52(3) \\
0.47(3) \\
0.50(3)\end{array}$ & $\begin{array}{l}0.63(4) \\
0.56(2) \\
0.59(3)\end{array}$ & $\begin{array}{l}1.11(4) \\
0.83(3) \\
0.77(3)\end{array}$ & $\begin{array}{l}1.03(3) \\
0.82(3) \\
0.72(3)\end{array}$ & $\begin{array}{l}0.98(4) \\
0.80(2) \\
0.73(3)\end{array}$ & $\begin{array}{l}0.71(4) \\
0.48(3) \\
0.46(3)\end{array}$ & $\begin{array}{l}0.54(3) \\
0.39(3) \\
0.35(3)\end{array}$ & $\begin{array}{l}0.61(4) \\
0.45 \text { (2) } \\
0.44 \text { (3) }\end{array}$ \\
\hline
\end{tabular}

* Figures in parentheses indicate in all tables the number of experiments in each group.

measured after different periods of incubation of living and heat-inactivated samples. The data obtained in these experiments are shown in Figure 1 and Tables I and II.

The data plotted in Figure 1 indicate that a steady state for $\mathrm{Ca}$ concentration in the medium surrounding heat-inactivated bone samples was established by 2 hours, while the maximal concentration for living samples was not reached until 16 hours, although it was closely approached by 6 hours. Practically identical curves were obtained for $\mathrm{P}$ concentration.

These results (Figure 1) suggested that the greatest differences in $\mathrm{Ca}$ concentration between living and dead bone samples would be observed if the incubations were conducted for 16 hours, but, as can be seen from Table II, bone samples incubated for this period of time without glucose were no longer viable. This indicated that if the relation of glucose metabolism to $\mathrm{Ca}$ and $\mathrm{P}$ concentrations in the medium was to be examined, an incubation period shorter than 16 hours would be required. Six hours was selected as a suitable time. In addition, incubation for 4 hours was conducted in some experiments.

The concentrations of calcium observed for living samples after 6 hours varied from day to day between 0.58 and 0.78 mmole per $\mathrm{L}$ (mean, $0.76)$ while inorganic phosphorus concentrations

TABLE II

Effects of glucose deprivation; normal bone

\begin{tabular}{lcccc}
\hline & & \multicolumn{3}{c}{$\mathrm{Ca}$} \\
\cline { 3 - 4 } $\begin{array}{c}\text { Exp. } \\
\text { day }\end{array}$ & $\begin{array}{c}\text { Incub., } \\
\text { hours }\end{array}$ & +Glucose & $\overline{\text { s Glucose }}$ \\
\hline 4 & 16 & $0.73(3)$ & $0.66(3)$ \\
5 & 16 & $0.60(6)$ & $0.52(6)$ \\
6 & 16 & $0.72(3)$ & $0.66(3)$ \\
7 & 16 & $0.80(3)$ & $0.72(3)$ \\
& Viability of samples & + & 0 \\
\hline
\end{tabular}

varied between 0.72 and 1.11 mmoles per $L$ (mean, 0.92). These mean values are both below those expected in the extracellular fluid of this species on the basis of serum analysis, although the relatively higher phosphate concentration is present in the serum also. The very slowly rising values (shown for $\mathrm{Ca}$ in Figure 1) with increasing periods of incubation beyond 6 hours suggest that, had it been possible for the incubation time to be much longer, values more like extracellular fluid might have been reached. Unfortunately this was not practicable, since cellular metabolism becomes very variable and tends to slow down or cease when incubations of more than 24 hours are carried out.

$\mathrm{Ca}, \mathrm{P}$, and $\mathrm{Ca} \times \mathrm{P}$ concentrations found in media after 6-hour incubations of living and heatinactivated samples are shown in Table I. Since $\mathrm{Ca}, \mathrm{P}$, and $\mathrm{Ca} \times \mathrm{P}$ concentrations were lower for heat-inactivated samples, it can be inferred that 82.4 per cent of the $\mathrm{Ca}$ concentration, 95.2 per cent of the $\mathrm{P}$ concentration, and 78.1 per cent of the $\mathrm{Ca} \times \mathrm{P}$ concentration were the result of passive mineral solubilty. The balance could be attributed to cellular activity. The depression in Ca concentration produced by inactivation of cells due to prolonged deprivation of glucose (Table II) approached that produced by heat-inactivation. This finding, together with the similarity in $\mathrm{Ca}$ concentration at 2 hours between living and heatinactivated samples (Figure 1) suggests that in both experiments the reduction was the result of cessation of cellular metabolism rather than of changes in mineral solubility produced by heat or changes in $\mathrm{Ca}$ and $\mathrm{P}$ diffusion produced by the heating process. ${ }^{4}$

4 Additional evidence in favor of this view was obtained from incubations at a low $\mathrm{pH}$ where no differences were seen between living and heat-inactivated bones (unpublished studies). 
TABLE III

Effects of glucose deprivation; normal bone

\begin{tabular}{|c|c|c|c|c|c|c|c|c|c|}
\hline \multirow{2}{*}{$\begin{array}{l}\text { Exp. } \\
\text { day }\end{array}$} & \multirow{2}{*}{$\begin{array}{l}\text { Incub., } \\
\text { hours }\end{array}$} & \multicolumn{2}{|c|}{$\mathrm{Ca}$} & \multicolumn{2}{|c|}{$\mathbf{P}$} & \multicolumn{2}{|c|}{$\mathrm{Ca} \times \mathrm{P}$} & \multicolumn{2}{|c|}{ (Glucose-ō glucose) } \\
\hline & & +Glucose & s Glucose & +Glucose & $\overline{\text { s Glucose }}$ & +Glucose & $\overline{\text { s Glucose }}$ & $\mathrm{Ca}$ & $\mathbf{P}$ \\
\hline $\begin{array}{r}8 \\
9 \\
10 \\
11 \\
12 \\
13\end{array}$ & $\begin{array}{l}4 \\
4 \\
4 \\
4 \\
4 \\
4\end{array}$ & $\begin{array}{l}0.70(4) \\
0.78(4) \\
0.77(4) \\
0.91(4) \\
0.63(4) \\
0.80(4)\end{array}$ & $\begin{array}{l}0.63(4) \\
0.70(4) \\
0.73(4) \\
0.85(3) \\
0.61(4) \\
0.73(4)\end{array}$ & $\begin{array}{l}0.62(4) \\
0.64(4) \\
\\
0.55(4) \\
0.59(4) \\
0.56(4)\end{array}$ & $\begin{array}{l}0.60(4) \\
0.61(4) \\
0.59(4) \\
0.62(4) \\
0.58(4)\end{array}$ & $\begin{array}{l}0.45(4) \\
0.50(4) \\
\\
0.50(3) \\
0.37(4) \\
0.45(4)\end{array}$ & $\begin{array}{l}0.39(4) \\
0.43(4) \\
\\
0.50(3) \\
0.38(4) \\
0.43(3)\end{array}$ & $\begin{array}{r}+0.07 \\
+0.08 \\
+0.04 \\
+0.06 \\
+0.02 \\
+0.07\end{array}$ & $\begin{array}{r}+0.02 \\
+0.03 \\
-0.04 \\
-0.03 \\
-0.02\end{array}$ \\
\hline $\begin{array}{l}14 \\
15 \\
16 \\
17\end{array}$ & $\begin{array}{l}6 \\
6 \\
6 \\
6\end{array}$ & $\begin{array}{l}0.78(3) \\
0.71(3) \\
0.74(2) \\
0.66(3)\end{array}$ & $\begin{array}{l}0.68(3) \\
0.66(3) \\
0.65(2) \\
0.64(3)\end{array}$ & $\begin{array}{l}0.99(3) \\
0.93(3) \\
0.95(2) \\
1.07(3)\end{array}$ & $\begin{array}{l}1.01(3) \\
0.96(3) \\
0.90(2) \\
1.04(3)\end{array}$ & $\begin{array}{l}0.78(3) \\
0.66(3) \\
0.71(2) \\
0.71(3)\end{array}$ & $\begin{array}{l}0.69(3) \\
0.64(3) \\
0.59(2) \\
0.67(3)\end{array}$ & $\begin{array}{r}+0.10 \\
+0.05 \\
+0.09 \\
+0.02\end{array}$ & $\begin{array}{r}-0.03 \\
-0.03 \\
+0.05 \\
+0.03\end{array}$ \\
\hline
\end{tabular}

\section{B. Effects of changes in glucose metabolism}

1. Glucose deprivation. While glucose deprivation for 16 hours was not compatible with survival, 4 and 6 hours without this substrate was well tolerated since, in a subsequent incubation of the same samples with glucose, the lactate production was resumed at close to the normal rate. As can be seen from Table III, lack of glucose depressed $\mathrm{Ca}$ concentration 7 and 8.2 per cent and lactate production 91.1 and 94.1 per cent after 4 and 6 hours, respectively. The $\mathrm{Ca} \times \mathrm{P}$ products were similarly reduced. In none of these experiments was there any difference in $\mathrm{P}$ concentrations, while the differences in $\mathrm{Ca}$ concentrations, although small, were highly significant. Differences in the $\mathrm{Ca} \times \mathrm{P}$ product (due almost wholly to changes in $\mathrm{Ca}$ ) were statistically significant after 6 hours.

In separate experiments the influence of the presence of glucose on heat-inactivated bones was studied. No significant differences in $\mathrm{Ca}$ or $\mathrm{P}$ between samples incubated with and without glucose were found and, hence, the possibility was ex- cluded that the effects of glucose were unrelated to its metabolism.

2. Iodoacetate inhibition. In an attempt to localize the effect of glucose metabolism, glycolysis was blocked at the triose phosphate dehydrogenase level with iodoacetate (IA). When this inhibitor was added to the media (Table IV), Ca was depressed 5.1 and 5.9 per cent and lactate 94.1 and 94.5 per cent after 4 and 6 hours. The $\mathrm{Ca} \times \mathrm{P}$ product was decreased 7.9 per cent at 6 hours. Again the differences in Ca were highly significant, while $P$ was not significantly influenced. However, two possibilities exist that this effect of IA was not due solely to interference with glucose metabolism. First, the IA ion as such might have an effect on the passive solubility of bone mineral, and second, IA might kill the cells (9); but, when samples were incubated without substrate, or with pyruvate instead of glucose, IA had no significant influence on $\mathrm{Ca}$ concentrations. If the cells had been killed, lower $\mathrm{Ca}$ concentrations would have been expected on the basis of the data obtained with heat or glucose deprivation, as shown in Tables I and II. On the other hand, if IA had had

TABLE IV

Effects of iodoacetate (IA) inhibition; normal bone

\begin{tabular}{|c|c|c|c|c|c|c|c|}
\hline \multirow[b]{2}{*}{$\begin{array}{l}\text { Exp. } \\
\text { day }\end{array}$} & \multirow[b]{2}{*}{$\begin{array}{l}\text { Incub., } \\
\text { hours }\end{array}$} & \multicolumn{2}{|c|}{$\mathrm{Ca}$} & \multicolumn{2}{|c|}{$\mathbf{P}$} & \multicolumn{2}{|c|}{$\mathrm{Ca} \times \mathrm{P}$} \\
\hline & & $\begin{array}{c}\text { Controls, } \\
\text { normal }\end{array}$ & $\begin{array}{c}\text { +IA } \\
\text { normal }\end{array}$ & $\begin{array}{c}\text { Controls, } \\
\text { normal }\end{array}$ & $\begin{array}{c}\text { +IA, } \\
\text { normal }\end{array}$ & $\begin{array}{l}\text { Controls, } \\
\text { normal }\end{array}$ & $\begin{array}{l}\text { +IA, } \\
\text { normal }\end{array}$ \\
\hline $\begin{array}{l}18 \\
19 \\
20\end{array}$ & $\begin{array}{l}4 \\
4 \\
4\end{array}$ & $\begin{array}{l}0.66(4) \\
0.80(3) \\
0.69(3)\end{array}$ & $\begin{array}{l}0.62(4) \\
0.75(3) \\
0.66(3)\end{array}$ & & & & \\
\hline $\begin{array}{l}21 \\
22\end{array}$ & $\begin{array}{l}6 \\
6\end{array}$ & $\begin{array}{l}0.71(6) \\
0.70(4)\end{array}$ & $\begin{array}{l}0.67(6) \\
0.65(4)\end{array}$ & $\begin{array}{l}0.89(6) \\
0.87(4)\end{array}$ & $\begin{array}{l}0.86(6) \\
0.88(4)\end{array}$ & $\begin{array}{l}0.64(6) \\
0.61(4)\end{array}$ & $\begin{array}{l}0.58(6) \\
0.58(4)\end{array}$ \\
\hline
\end{tabular}


TABLE $\mathbf{V}$

Effects of anaerobiasis; normal bone

\begin{tabular}{|c|c|c|c|c|c|c|c|}
\hline \multirow[b]{2}{*}{$\begin{array}{l}\text { Exp. } \\
\text { day. }\end{array}$} & \multirow[b]{2}{*}{$\begin{array}{l}\text { Incub., } \\
\text { hours }\end{array}$} & \multicolumn{2}{|c|}{$\mathrm{Ca}$} & \multicolumn{2}{|c|}{$\mathbf{P}$} & \multicolumn{2}{|c|}{$\mathrm{Ca} \times \mathrm{P}$} \\
\hline & & $\begin{array}{c}\text { Controls, } \\
\text { normal }\end{array}$ & $\begin{array}{c}\text { Anaerobic, } \\
\text { normal }\end{array}$ & $\begin{array}{c}\text { Controls, } \\
\text { normal }\end{array}$ & $\underset{\text { Anaerobic, }}{\text { normal }}$ & $\begin{array}{c}\text { Controls, } \\
\text { normal }\end{array}$ & $\underset{\text { normal }}{\text { Anaerobic, }}$ \\
\hline $\begin{array}{l}23 \\
24 \\
25\end{array}$ & $\begin{array}{l}4 \\
4 \\
4\end{array}$ & $\begin{array}{l}0.78(4) \\
0.80(4) \\
0.80(4)\end{array}$ & $\begin{array}{l}0.76(4) \\
0.80(4) \\
0.75(4)\end{array}$ & $\begin{array}{l}0.64(4) \\
0.63(4) \\
0.64(4)\end{array}$ & $\begin{array}{l}0.62(4) \\
0.64(4) \\
0.62(4)\end{array}$ & $\begin{array}{l}0.50(4) \\
0.50(4) \\
0.51(4)\end{array}$ & $\begin{array}{l}0.47(4) \\
0.51(4) \\
0.47(4)\end{array}$ \\
\hline $\begin{array}{l}26 \\
27\end{array}$ & $\begin{array}{l}6 \\
6\end{array}$ & $\begin{array}{l}0.75(6) \\
0.70(4)\end{array}$ & $\begin{array}{l}0.75(6) \\
0.66(3)\end{array}$ & $\begin{array}{l}0.91(6) \\
0.87(4)\end{array}$ & $\begin{array}{l}0.93(6) \\
0.90(3)\end{array}$ & $\begin{array}{l}0.68 \text { (6) } \\
0.61(4)\end{array}$ & $\begin{array}{l}0.71(6) \\
0.60(3)\end{array}$ \\
\hline
\end{tabular}

a direct effect on passive mineral solubility, this should have been reflected by change in $\mathrm{Ca}$ concentration in experiments using samples incubated without substrate or with pyruvate.

3. Anaerobiasis. It has been suggested by other workers that the metabolically dependent fraction of the circulation $\mathrm{Ca}^{++}$concentration might be due to the local production of citric acid by the bone cells $(2,10-14)$. However, the amounts of citrate produced by bone cells in vitro is extremely small (1 to 2 per cent) compared with lactate (3). Furthermore, since about 80 per cent of the glucose utilized by the cells could be accounted for as lactate, it was suggested that lactic acid might be of primary and citric acid of only secondary importance in mobilizing $\mathrm{Ca}$ and $\mathrm{P}$ from bone mineral in vivo (3). For these reasons it was of interest to explore the effects of increased rates of lactate production on $\mathrm{Ca}$ and $\mathrm{P}$ concentrations.

In Table $\mathrm{V}$ the results of experiments in which samples were incubated anaerobically (nitrogen 95, $\mathrm{CO}_{2} 5$ per cent) are compared with controls under aerobic conditions. The results are basically the same after 4 and 6 hours. Anaerobically, 15.5 to 17.8 per cent more lactate was produced, while the $\mathrm{Ca}, \mathrm{P}$, and the $\mathrm{Ca} \times \mathrm{P}$ products were not significantly affected. In fact, in both series of experiments $\mathrm{Ca}$ values, the chief variable, were slightly depressed. These experiments therefore suggest that the rate of lactate production per se is not the critical factor involved in the mobilization of $\mathrm{Ca}$ from bone mineral.

\section{Studies with bone from animals treated with parathyroid hormone}

Bones from mice injected with parathyroid hormone were incubated for 6 hours with and without glucose and compared with controls. Thus, each experiment consisted of four groups. There were three samples in each group, and four such experiments were conducted. The values obtained are shown in Table VI and Figure 2. Three points of interest should be noted.

First, in the hormone-treated group with glucose present as substrate the concentrations of $\mathrm{Ca}$ and the $\mathrm{Ca} \times \mathrm{P}$ product were higher than for their normal counterparts. This is in agreement with the findings of others $(15,16)$. Second, the glucose effects on the concentrations of $\mathrm{Ca}$ and the $\mathrm{Ca} \times \mathrm{P}$ product were relatively more pronounced in the hormone-treated group than in controls, suggesting synergistic effects of glucose and hormone on the mobilization of $\mathrm{Ca}$. The relative differences between samples with and without glucose for both groups are shown in Figure 2. This pattern was the same in all ex-

TABLE VI

Effects of treatment with PTE (in vivo) and of glucose*

\begin{tabular}{|c|c|c|c|c|c|c|c|c|c|}
\hline \multirow{2}{*}{$\begin{array}{l}\text { Exp. } \\
\text { day }\end{array}$} & \multirow{2}{*}{$\begin{array}{l}\text { Incub., } \\
\text { hours }\end{array}$} & \multicolumn{2}{|c|}{$\mathrm{Ca}$} & \multicolumn{2}{|c|}{$\mathbf{P}$} & \multicolumn{2}{|c|}{$\mathrm{Ca} \times \mathrm{P}$} & \multicolumn{2}{|c|}{ (Glucose-s̄ glucose) } \\
\hline & & +Glucose & $\overline{\text { s Glucose }}$ & +Glucose & $\overline{\mathbf{s}}$ Glucose & +Glucose & $\overline{\text { s Glucose }}$ & $\mathrm{Ca}$ & $P$ \\
\hline $\begin{array}{l}14 \\
15 \\
16 \\
17\end{array}$ & $\begin{array}{l}6 \\
6 \\
6 \\
6\end{array}$ & $\begin{array}{l}0.92(3) \\
0.83(3) \\
0.84(2) \\
0.77(3)\end{array}$ & $\begin{array}{l}0.74(3) \\
0.76(3) \\
0.70(2) \\
0.68(3)\end{array}$ & $\begin{array}{l}1.00(3) \\
0.92(3) \\
0.88(2) \\
1.03(3)\end{array}$ & $\begin{array}{l}0.96(3) \\
0.88(3) \\
0.85(2) \\
1.04(3)\end{array}$ & $\begin{array}{l}0.92(3) \\
0.77(3) \\
0.73(2) \\
0.80(3)\end{array}$ & $\begin{array}{l}0.71(3) \\
0.67(3) \\
0.60(2) \\
0.71(3)\end{array}$ & $\begin{array}{l}+0.18 \\
+0.07 \\
+0.14 \\
+0.09\end{array}$ & $\begin{array}{l}+0.04 \\
+0.04 \\
+0.03 \\
-0.01\end{array}$ \\
\hline
\end{tabular}

* The data for samples from normal animals incubated on the same day appear in Table III. 


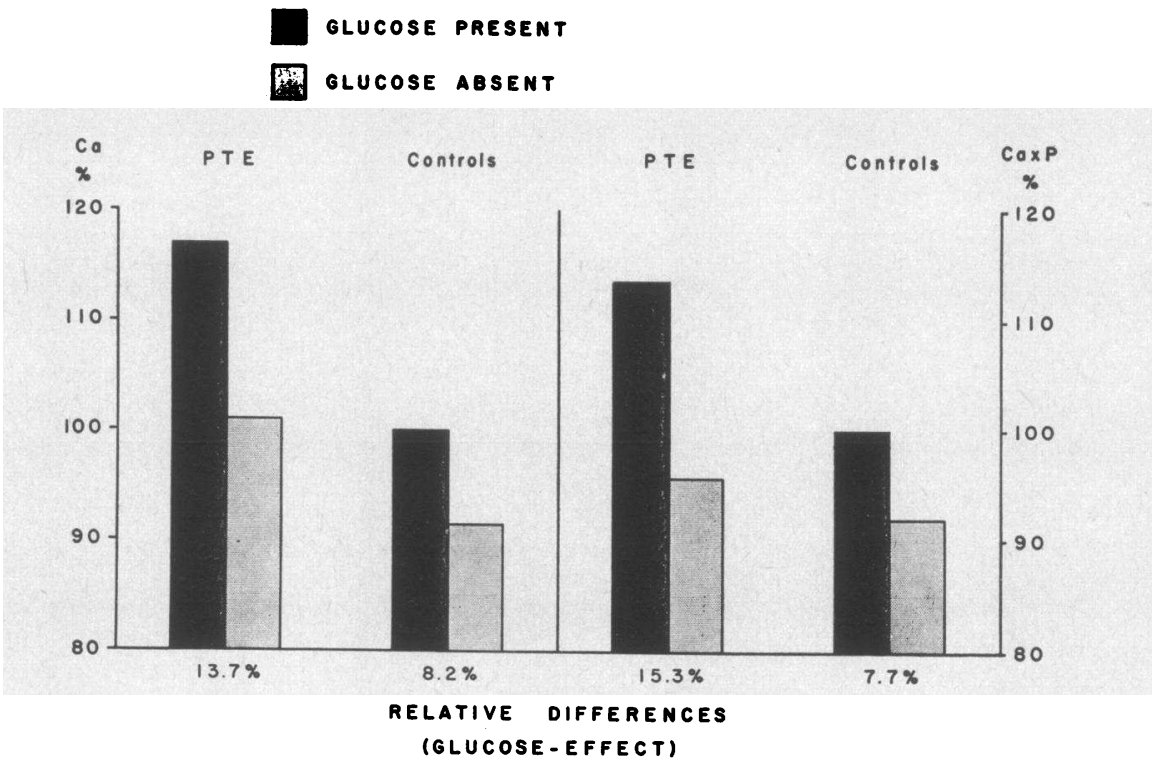

Fig. 2. "Steady state" $C A$ and $C A \times P$ concentrations in the media SURROUNDING BONES FRoM NORMAL AND PTE-TREATEd animals. Data from Table VI. Note the increase in the relative differences between samples incubated with and without glucose in the PTE group.

periments reported here and in a preliminary experiment run for 4 hours. There are several reports showing that the hormone is capable of modifying cell metabolism $(4,15-17)$, and in the present study such effects were demonstrated by an increase in lactate production of 22.3 per cent. Third, it appears that the values for $\mathrm{Ca}$ concentration and the $\mathrm{Ca} \times \mathrm{P}$ product were higher for the hormone-treated samples than for controls even without glucose, although the difference for the product was not significant. These findings suggested that the passive solubility of the bone mineral might have been increased by parathyroid treatment and that part of the increases in Ca concentration might have been the result of increases in passive solubilization of the mineral.

This suggestion was supported by the results of subsequent experiments using heat-inactivated bones from PTE-treated animals. The $\mathrm{Ca}$ concentrations and the $\mathrm{Ca} \times \mathrm{P}$ concentration products were significantly higher in these samples than in untreated heat-inactivated samples incubated at the same time (Table I). ${ }^{5}$ The Ca concentrations observed were practically as high as

5 This was true even after the bones had been washed by incubation for 1 hour before the ordinary incubation in fresh media. for normal, living bones supplied with glucose. Thus, the mineral of bones from PTE-treated animals appears to have an increased solubility independent of metabolism of surviving cells.

\section{Effects of final $p H$ in the medium}

It is well known that the solubility of bone mineral increases as $\mathrm{pH}$ decreases. Thus, if in

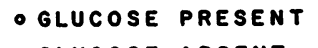

- gluCOSE ABSENT

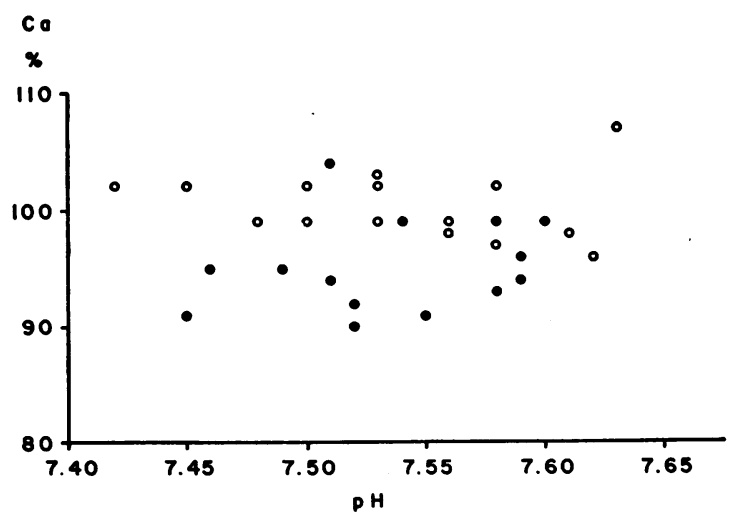

Fig. 3. "Steady state" Ca concentrations vs final PH IN THE MEDIA SURROUNDING BONES INCUBATED WITH AND WITHOUT GLUCOSE. Note lack of correlation between $\mathrm{Ca}$ concentrations and final $\mathrm{pH}$. 
these systems major $\mathrm{pH}$ changes occurred in the media during incubation, such changes alone might have been responsible for the mobilization of $\mathrm{Ca}$ from the bone samples. However, $\mathrm{pH}$ remained quite constant in the media including those in which $\mathrm{pH}$ changes might have been possible due to acid production by actively metabolizing cells. The variations that did occur could not be correlated with the final $\mathrm{Ca}$ concentrations observed. In Figure 3, $\mathrm{pH}$ values at the end of incubation are plotted against $\mathrm{Ca}$ concentrations to illustrate this point. The values are from experiments in which the effects of the presence of glucose were studied. It is apparent that only minor $\mathrm{pH}$ variations occurred, and these were practically equally distributed between the two groups. Also, Ca concentrations were independent of $\mathrm{pH}$ in this range. In the other experiments of this series a similar lack of correlation between $\mathrm{Ca}$ concentration and final $\mathrm{pH}$ of the medium was found.

\section{DISCUSSION}

In this study a correlation has been demonstrated between the rate of bone cellular metabolism and steady state $\mathrm{Ca}$ concentrations in the media. Except for the experiments with heatinactivated bones, no significant changes were obtained for $\mathrm{P}$ concentrations. When changes were seen in the $\mathrm{Ca} \times \mathrm{P}$ product, they were due to changes in $\mathrm{Ca}$. Just why this was true is not clear, but in view of the fact that bone mineral may exhibit molar $\mathrm{Ca} / \mathrm{P}$ ratios from 1.3 to 2 , differences in $\mathrm{Ca}$ may be more pronounced than for $\mathrm{P}$ when bone salt goes into solution. Furthermore, in equilibration studies with human powdered bone it has been demonstrated that lowering $\mathrm{pH}$ from about 7.8 to 6.6 resulted in steadily increased $\mathrm{Ca}$ concentrations, while total $\mathrm{P}$ concentrations remained unchanged (18). Consequently, if the metabolic effects demonstrated in the present studies were related to acid production and lowering of $\mathrm{pH}$ at the crystal surface (rather than in the medium), no change in total $\mathrm{P}$ might be seen. It should be noted that were citric acid the important metabolite, changes in $\mathrm{P}$ would be expected from Neuman's data, since he and his collaborator have shown that the increased solubility of hydroxyapatite caused by citrate in the surrounding fluid is accompanied by increases in phosphate which ap- pears to be displaced from the crystals by citrate in the equilibrium system which he studied (2).

A factor that might contribute to $\mathrm{Ca}$ and $\mathrm{P}$ mobilization would be an increased ionic strength due to accumulation of metabolites in a closed system, but for such changes to cause a significant decrease in the activity coefficients of $\mathrm{Ca}$ and $\mathrm{P}$ in the medium and thus increase the apparent mobilization of these ions, they would have to be far greater than those observed here. The maximal change that could be attributed to ionic strength changes in these systems was one-eighth of the rise seen in $\mathrm{Ca}$ concentrations. Thus, changes in ionic strength do not appear to have contributed significantly to the phenomena observed.

The maintenance of higher $\mathrm{Ca} \times \mathrm{P}$ concentrations in the media surrounding living rather than dead bones is in agreement with the findings of others. Basset and Nordin found that human bones, killed by repeated freezing-thawing reached equilibrium with a lower $\mathrm{Ca} \times \mathrm{P}$ product than that of viable bones (5). The results are also supported by Raisz, Au and Tepperman, who recently reported higher $\mathrm{Ca}$ concentrations in the incubating fluids for living than for heat-inactivated bones, using weanling rats (16). All these results most probably are related to the presence of cell activity in viable samples. The findings strongly support the concept that cell activity is involved in the regulation of serum $\mathrm{Ca} \times \mathrm{P}$ levels, and is at least partly responsible for the supersaturation of normal serum.

The absence of glucose as a substrate for surviving bones resulted in a depression of $\mathrm{Ca}$ concentrations that approximated 50 per cent of the depression observed in heat-inactivated bones, and the bones killed owing to glucose starvation for 16 hours exhibited $\mathrm{Ca}$ values between these two groups. The reason that the depression in all three groups was not the same may be that in the glucose-deprived groups endogenous sources of carbohydrate, although very small, may have been utilized. In addition, metabolism of other endogenous substrates may have contributed. In any case, the results indicate that the rate of carbohydrate metabolism in the bone cells significantly affects the $\mathrm{Ca}$ concentrations that will be maintained in the surrounding fluids.

In the iodoacetate group the depression in $\mathrm{Ca}$ concentrations was significant but somewhat less 
than in the glucose-deprived group. This might be explained partly by the increased ionic strength due to IA, and partly by metabolism above the block. However, the $\mathrm{Ca} \times \mathrm{P}$ products were the same in both groups, and the results suggest that the chief effects of glucose are dependent upon metabolism beyond triose phosphate dehydrogenase.

In the experiments in which the effects of glucose deprivation and iodoacetate were studied, a decrease in lactate of approximately 95 per cent was accompanied by a decrease in the $\mathrm{Ca} \times \mathrm{P}$ product of approximately 7 per cent. As appears from the experiments under anaerobic conditions, this simultaneous reduction does not mean that the product is directly influenced by the amount of lactate produced; rather, it suggests that the $\mathrm{Ca} \times$ $\mathrm{P}$ product is diminished when metabolism, as expressed by the dwindling lactate production, is being slowed down.

On the basis of the results reported, a tentative diagram illustrating the components of the total $\mathrm{Ca}$ concentration in the incubating media surrounding bone from normal and parathyroid hormone-treated animals can be constructed as shown in Figure 4. For the control animals the fraction of the total $\mathrm{Ca}$ that can be assigned to passive solubility is 82 per cent, while 18 per cent can be considered the result of cellular activity. As can be seen, approximately one-half of this cellular

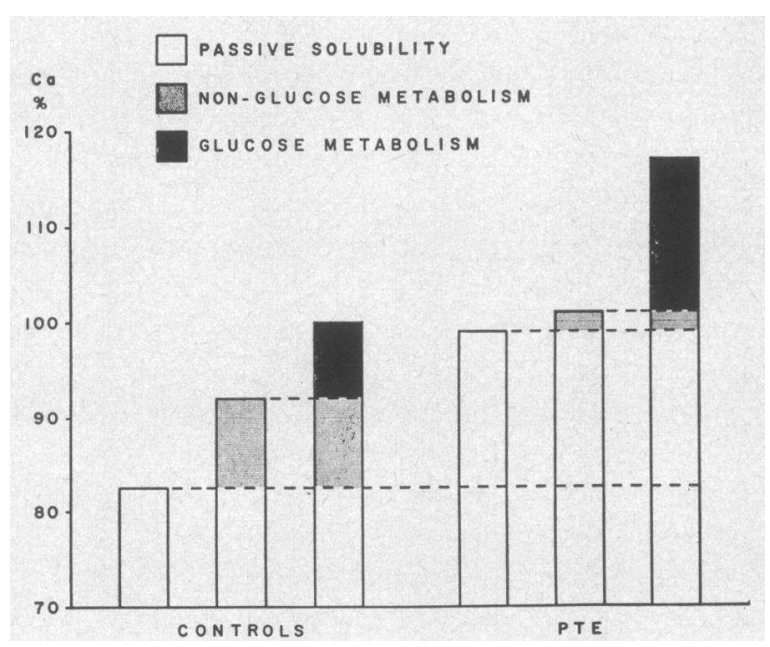

Fig. 4. Components of "steady state" Ca concenTRATIONS IN THE MEDIA SURROUNDING BONES FROM NORMAL AND PTE-TREATED ANIMALS UNDER VARIOUS INCUBating conditions. Data from Tables I and VI. "metabolic" fraction seems related to glucose metabolism and the remainder to other metabolic processes. In the parathyroid hormone-treated group the increment in total $\mathrm{Ca}$ concentration can be almost entirely attributed to increases in passive mineral solubility under the experimental conditions used here. However, although there is no apparent increase in the total size of the cellular "metabolic" component as compared with controls, the distribution between that which is glucose-dependent and that which is not has changed. The Ca-mobilizing effect related to glucose is enhanced, and the effect related to other metabolic phenomena is correspondingly reduced. A similar diagram for $\mathrm{Ca} \times \mathrm{P}$ products showed the same types of distribution.

The significance of the modification of the pattern induced by the hormone is unknown; the mechanism by which the hormone increases the passive solubility of the mineral remains equally obscure, although it may be related to the increase in citrate content in dry bone which appears following treatment with parathyroid hormone (15, 19). As has been pointed out by Thompson (20), the presence of citrate in synthetic hydroxyapatite increases the relative solubility of such minerals. Another possibility might be that hydrogen ions from acid metabolites displace $\mathrm{Ca}$ ions from the crystal surface, as suggested by Neuman $(2,14)$. Such an effect on the solid phase would change the thermodynamic properties of the crystal and increase the solubility of the mineral (14).

\section{SUMMARY}

1. Mouse calvaria have been incubated in vitro until a steady state distribution of $\mathrm{Ca}$ and $\mathrm{P}$ between medium and sample was reached. These studies were designed to examine the relative importance of passive mineral solubility and various aspects of bone cellular metabolism in the maintenance of $\mathrm{Ca}$ and $\mathrm{P}$ concentrations in body fluids.

2. Inactivation of cellular activity by heat and by long-lasting starvation depressed $\mathrm{Ca}$ concentrations in the media 17.6 and 12.6 per cent, respectively. In surviving bone, glucose deprivation and iodoacetate (IA) inhibition decreased $\mathrm{Ca}$ 8.2 and 5.9 per cent, respectively, and lactate production about 94 per cent. These differences were all highly significant $(p<0.001)$. P concentrations, however, were roughly the same in all ex- 
periments with surviving bones. While anaerobiasis increased lactate production 15.3 per cent, $\mathrm{Ca}$ was slightly decreased. The results support the concept that mobilization of $\mathrm{Ca}$ and $\mathrm{P}$ from bone mineral and the regulation of serum levels of these ions are dependent upon the rate and pattern of bone cell metabolism. Effects of glucose metabolism are dependent upon steps beyond triose phosphate dehydrogenase, but the rate of lactate production seems only indirectly involved.

3. Prior treatment with parathyroid extract (PTE) increased $\mathrm{Ca} 16.8$ and lactate 22.3 per cent in the media surrounding surviving bones. The increment in $\mathrm{Ca}$ concentration due to the hormone treatment appeared to be the result of a) an increase in passive solubility of the mineral, and $b$ ) a modification of the pattern of cellular metabolic effects.

\section{REFERENCES}

1. McLean, F. C., and Urist, M. R. Bone. An Introduction to the Physiology of Skeletal Tissue. Chicago, Univ. of Chicago Press, 1955.

2. Neuman, W. F., and Neuman, M. W. The Chemical Dynamics of Bone Mineral. Chicago, Univ. of Chicago Press, 1958.

3. Borle, A. B., Nichols, N., and Nichols, G., Jr. Metabolic studies of bone in vitro. I. Normal bone. J. biol. Chem. 1960, 235, 1206.

4. Borle, A. B., Nichols, N., and Nichols, G., Jr. Metabolic studies of bone in vitro. II. The metabolic patterns of accretion and resorption. J. biol. Chem. 1960, 235, 1211.

5. Basset, C. A. L., and Nordin, B. E. C. The "calcium-phosphate product" in an in vitro system of surviving bone. Acta orthop. scand. 1959, 28, 241.

6. Brenneman, F. N., and Volk, W. A. Glyceraldehyde phosphate dehydrogenase activity with triphosphopyridine nucleotide and diphosphopyridine nucleotide. J. biol. Chem. 1959, 234, 2443.

7. Fiske, C. H., and Subbarow, Y. The colorometric determination of phosphorus. J. biol. Chem. 1925, 66,375 .
8. Barker, S. B., and Summerson, W. H. The colorometric determination of lactic acid in biological material. J. biol. Chem. 1941, 138, 535.

9. Lundsgaard, E. Weitere Untersuchungen über Muskelkontraktionen ohne Milchsäurebildung. Biochem. Z. 1930, 227, 51.

10. Firschein, H., Martin, G., Mulryan, B. J., Strates, B., and Neuman, W. F. Concerning the mechanism of action of parathyroid hormone. I. Ion-gradients. J. Amer. chem. Soc. 1958, 80, 1619.

11. Martin, G. R., Firschein, H. E., Mulryan, B. J., and Neuman, W. F. Concerning the mechanism of action of parathyroid hormone. II. Metabolic effects. J. Amer. chem. Soc. 1958, 80, 6201.

12. Dixon, T. F., and Perkins, H. R. The chemistry of calcification in The Biochemistry and Physiology of Bone, G. H. Bourne, Ed. New York, Academic Press, 1956, p. 287.

13. Freeman, S. Citrate metabolism with special reference to calcium and bone in Bone as a Tissue, $\mathrm{K}$. Rodahl, J. T. Nicholson and E. M. Brown, Jr., Eds. New York, McGraw-Hill, 1960.

14. Neuman, W. F. The mechanism of parathyroid function. J.-Lancet 1958, 78, 190.

15. Vaes, G., and Nichols, G., Jr. Metabolic studies of bone in vitro. III. Citric acid metabolism and bone mineral solubility. Effects of parathyroid hormone and estradiol. J. biol. Chem. In press. Vaes, G., and Nichols, G., Jr. Effects of a massive dose of parathyroid extract on bone metabolic pathways. Endocrinology. In press.

16. Raisz, L. G., Au, W. Y. W., and Tepperman, J. Effect of parathyroids on bone metabolism in vitro. Acta endocr. (Kbh.) 1960, 35, suppl. 51, p. 487.

17. Laskin, D. M., and Engel, M. B. Bone metabolism and bone resorption after parathyroid extract. Arch. Path. (Chicago) 1956, 62, 296.

18. MacGregor, J., and Nordin, B. E. C. Equilibration studies with human bone powder. J. biol. Chem. 1960, 235, 1215.

19. Dickens, F. The citric acid content of animal tissues, with reference to its occurrence in bone and tumour. Biochem. J. 1941, 35, 1011.

20. Thompson, M. M. S. Studies on the Interaction of Citrate with the Bone Mineral. Thesis. Cambridge, Mass., Radcliffe College, 1956. 